\title{
Time series data for Canadian arctic vertebrates: IPY contributions to science, management, and policy
}

\author{
S. H. Ferguson • D. Berteaux • A. J. Gaston • \\ J. W. Higdon • N. Lecomte • N. Lunn • M. L. Mallory • \\ J. Reist • D. Russell • N. G. Yoccoz $・$ X. Zhu
}

Received: 16 January 2012 / Accepted: 17 April 2012

(C) Crown Copyright as represented by: Tanuja Kulkarni 2012

\begin{abstract}
Long-term data are critically important to science, management, and policy formation. Here we describe a number of data collections from arctic Canada that monitor vertebrate population trends of freshwater and marine fish, marine birds, marine and
\end{abstract}

Electronic supplementary material The online version of this article (doi:10.1007/s10584-012-0476-7) contains supplementary material, which is available to authorized users.

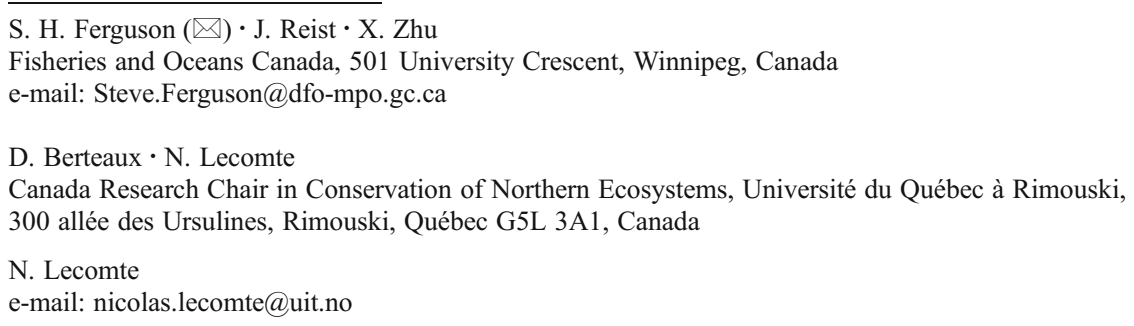

\section{A. J. Gaston}

Canadian Wildlife Service, National Wildlife Research Centre, Carleton University, Ottawa, Ontario K1A 0H3, Canada

J. W. Higdon

Consulting Wildlife Biologist, Winnipeg, Canada

\section{N. Lecomte}

Department of Environment, Government of Nunavut, Igloolik, Nunavut, Canada

\section{N. Lunn}

Wildlife Research Division, S\&T, Environment Canada, 5320-122 St., Edmonton, Canada

\section{L. Mallory}

Biology Department, Acadia University, 33 Westwood Ave., Wolfville, NS B4P 2R6, Canada

D. Russell

Environment Canada, Canadian Wildlife Service, Yellowknife, Canada

N. Lecomte $\cdot$ N. G. Yoccoz

Department of Arctic and Marine Biology, University of Tromsø, 9037 Tromsø, Norway 
terrestrial mammals. These time series data cover the last ca. 30 years and capture a period from the onset of global changes affecting the Arctic up to recent years with a rapid increase in temperature. While many of these data collections were initiated through a variety of government and university programs, they also include a surge in polar research launched with the recent International Polar Year (2007-2008). We estimated the long-term vertebrate index from our data that summarizes various taxa abundance trends within a global context and observed a continuous decline of about $30 \%$ in population abundance since the 1990s. Though most data collections are biased towards few taxa, we conduct time-series analyses to show that the potential value of long-term data emerges as individual monitoring sites can be spread across space and time scales. Despite covering a handful of populations, the different time series data covered a large spectrum of dynamics, cyclic to non-cyclic, including coherence with the North Atlantic Oscillation, lag effects, and density dependence. We describe a synthesis framework to integrate ecological time-series research and thereby derive additional benefits to management, science, and policy. Future requirements include: (1) continuation of current observation systems; (2) expansion of current monitoring sites to include additional trophic links and taxonomic indicators; (3) expansion beyond the existing program to include greater spatial coverage into less-sampled ecosystems and key representative locations; and (4) integration of circumpolar observations and comprehensive analyses. Development of a circumpolar observation system is necessary for innovative science, large-scale adaptive management, and policy revision essential to respond to rapid global change.

"The most important underlying message is that, in ecological research, long-term studies are critical and pay off the most - and keeping your mind open to the possible importance of unpredicted results is a critical component." Ian Stirling

\section{Introduction}

The Arctic has experienced a significant warming trend over the past 30 years and its land, freshwater, and marine ecosystems are already changing in response (Arctic Climate Impact Assessment ACIA 2005; Blunden et al. 2011). Up to now, the changes observed are numerous. They include a general "greening" of the arctic landscape, a reshuffling in species richness, abundance and spatial distribution, as well as an alteration of geophysical and biochemical processes and cycles at local, regional and pan-arctic scales (Post et al. 2009). Though few, the existing long-term (decade-scale) monitoring in this biome provides critical information that builds towards high-impact science, including the fodder to test ecological theory in ways that are not possible based on typical short-term studies. Most studies are short-term ( $<4$ years), and biological factors (e.g., predation) tend to predominate as explanations of ecological patterns, whereas for long-term studies climatic patterns predominate (Edwards et al. 2010). Even among long-term studies the spatial scale is often limited, creating problems in understanding ecosystem connections and interactions among water, land, and air (Peters et al. 2008). Integrating several long-term monitoring studies thus offers the opportunity to develop a large spatial scale perspective of ecosystem functioning while expanding existing concepts and theories beyond what is provided by simply summing the separate parts.

Long-term data often provide conclusions that are unanticipated and consequently can have great impact on policy decisions and be of great interest to an informed public (Youngblut 2009). Thus, there is a growing need for strategic expansion of baseline data to assess rates of biodiversity and ecosystem change, and to determine possible mitigation 
and/or adaptation approaches (Carpenter et al. 2009; Magurran et al. 2010). Long-term data collections have frequently been used to inform government policy. For example, the measured increase in acid rain in North America that resulted in destruction of many forests and the acidification of numerous lakes during 1970-1980 (Likens and Bormann 1974; Jeffries 1997). Because of such measurements, Canada experienced major legislative changes related to pollution laws. Further, to prove the effects of DDT on animal health and breeding, the research required long-term generational data for affected populations (Ottoboni et al. 1977) but this resulted in strong societal attitude changes and government action. Effects of oil spills on long-lived mammals also required long-term data (Harwell and Gentile 2006) that can then be used to inform governments and trigger measures to develop safer oil and gas exploration, extraction, and shipping methods (Eicken et al. 2011).

Arctic ecosystems are under growing pressure from a variety of major anthropogenic stressors, e.g. increased shipping activity, climate change, resource development, increased human populations (Mallory et al. 2006). Addressing these pressures requires that stakeholders have access to comprehensive data on wildlife distribution and abundance trends in a timely manner (Arctic Climate Impact Assessment ACIA 2005). Unfortunately, existing longterm monitoring programs remain largely underfunded and uncoordinated toward a common goal. However, the last International Polar Year (IPY) (2007-2008) provided an increase in funding and logistical support to improve our ability to understand and interpret data from monitoring efforts, with the hope that future conservation efforts could respond to arctic-wide trends (Gofman 2010). Comprehensive monitoring of arctic ecosystems can assist society in maintaining a functioning system while providing necessary information for northerners who rely on the local environment for their economic and cultural needs (Butchart et al. 2010).

Understanding patterns in ecology often requires data collected over the long-term, but it may be difficult to discern the mechanism of change when multiple processes are involved (e.g. Peters 2010). Hence, appropriate monitoring not only requires data collected for long periods, but it also requires the identification of key ecosystem components and drivers, necessitating the need to select priority parameters and indicators. One example of the value of long time series data is the Continuous Plankton Recorder (CPR) dataset, begun in 1925, which provides a remarkable oceanic plankton and fishery data set that has been used to assess ecosystem responses to climate warming (Kirby et al. 2007). Over time the CPR has allowed the identification of spatial regions (with ca. 10 years of data), linear trends (with ca. 20 years), and a 3-year periodicity identified with spectral analysis (run across 30 years; see methods for details on this approach also used here). These results greatly helped to move to a new marine ecosystem paradigm linking variations in primary productivity (Bezemer and van der Putten 2007) to climatic systems such as the North Atlantic Oscillation, trophic relationships (top-down and bottom-up), and regime shifts across multiple trophic levels (Möllmann et al. 2008). In fact, the analyses of long-term patterns are our only practical and defensible approach to separate anthropogenic-induced change from natural variations across time and space, as no experiments can be performed across such scales.

Long-term data are also essential to detect "ecological surprises", or unexpected findings about the natural environment (Lindenmayer et al. 2010), because some key phenomena are not apparent unless populations, ecosystems, or ecological processes are studied for a long time. For example, in the case of acid rain in eastern North America, the negative influence of El Niño events on ecosystem recovery was only discerned through interpretation of anomalies in the long-term water chemistry monitoring of lakes and streams (e.g., Dillon et al. 1997). Similarly, changes in fish communities in northern Hudson Bay were only recognized by long-term monitoring of seabird diets at Coats Island (Gaston et al. 2003). Hence, long-term data are also important in ecology because they generate questioning and 
reformulating of views of the natural world, challenge current predictions about ecological trends and phenomena, and provide the ability to assess the effectiveness of resource management decisions.

Here, we describe a number of long-term vertebrate data collections that have benefited from IPY science and associated funding and discuss how their cumulative value is greater than the sum of their parts. For the latter, we conduct trend analyses to portray the collective significance of long-term data to science, management, and policy.

\section{Materials and methods}

Here we summarize the six IPY-sponsored research projects that provided long-term vertebrate monitoring (Table 1) Including research methods, data, and major concerns on representative vertebrates :

\subsection{Polar bears}

From 1984 to 2004, the Canadian Wildlife Service (CWS) used helicopters to capture polar bears during the ice-free period (between August and October) in the western Hudson Bay region (Stirling et al. 1989). Sample size varied annually with funding, but an attempt was made to evenly distribute capture effort over the entire study area (a $12,000-\mathrm{km}^{2}$ area between the community of Churchill and the Nelson River, Regehr et al. 2007). All observed polar bears were captured regardless of sex, age, or reproductive status, with the exception of some pregnant females that took refuge in dens. Captured polar bears were ear-tagged with a unique identification number and permanent tattoos to both sides of the inner surface of the upper lip. The Manitoba Department of Conservation (MDOC) also captures problem bears in and around Churchill, which are handled in a similar manner as the CWS protocol. Regehr et al. (2007) used the CWS and MDOC datasets for capture-recapture analyses of population size and trends. While the polar bear data used in our time series analyses were not directly generated via IPY funding, several IPY projects (GWAMM and PET) assisted in linking research results on the predator with their prey (ice seals), as well as enhancing an understanding of ecosystem effects.

\subsection{Caribou}

The frequency and methodology for monitoring the 12 migratory tundra caribou herds in Canada varies regionally. Despite this limitation, some generalizations regarding abundance can be made (Vors and Boyce 2009). Herds were low in the early 1970s, increased through the 1980s and early 1990s and then generally declined in the first decade of the 21 st century (http://www.carmanetwork.com). The latest estimates indicate that some of these herds are once again either stabilizing or recovering. The rates of increase and decline varied dramatically during this period. For example the Porcupine herd increased from 100,000 to 178,000 between 1970 and 1989 then declined to 123,000 by 2001 to again recover to 169,000 in 2010. Over a similar time period the George River herd increased from 105,000 to 780,000 and is currently estimated at 74,000. As can be imagined, managing herds whose abundance varied so dramatically and are such a critical resource to northern peoples is challenging. In response to that challenge, a group was formed in 2004 (CARMA) to share information, standardize monitoring techniques, and develop decision-support tools in an attempt to 
Table 1 Descriptions of six International Polar Year projects funded by the Canadian government that augmented long-term monitoring projects

\begin{tabular}{ll}
\hline IPY Project & Project focus and goals \\
\hline $\begin{array}{l}\text { Global Warming and Marine } \\
\text { Mammals (GWAMM) }\end{array}$ & $\begin{array}{l}\text { Developing community-based monitoring of marine mammals in } \\
\text { the greater Hudson Bay region. The main goal was to monitor } \\
\text { marine ecosystem change using apex predators to understand the } \\
\text { drivers of change, in order to provide policy information. Derived } \\
\text { information could then assist northerners to adapt to the marine } \\
\text { ecosystem changes associated with polar warming and the } \\
\text { resulting changes to marine mammal distribution and abundance. }\end{array}$
\end{tabular}

Polar Ecosystems in Transition (PET)

An interdisciplinary case study of the effects of climate change on temporal trends in contaminant accumulation, foraging ecology and human use of polar bears (Ursus maritimus). The main goal was to test for predator-prey relationships between polar bears and ice-seals through community monitoring efforts in the greater Hudson Bay region. Information gathered provided a holistic view of polar bear ecology that incorporated traditional ecological knowledge and Inuit participation in research.

CARMA Network

The CARMA Network examined impacts of the human/caribou (Rangiger tarandus) systems in the circumpolar Arctic. The main goal was to assess the impacts of global change on the world's migratory tundra caribou populations. Population estimates have been used to track the current declines in many of these herds. Standardizing field protocols and funding collection projects enabled CARMA to link impacts of change between environment, individuals and populations. Although CARMA's scope was global, a significant focus was on Canadian herds as Canada is the home to over $50 \%$ of the world's migratory tundra caribou

Climate Variability and Change:

The project studied the effects of climate change on chars

Effects on Char in the Arctic (CVCC) throughout the Canadian Arctic. Chars (fish) have a circumpolar distribution, are important components of Northern cultures and economies, and have adaptations for many aquatic ecosystems with differing climate systems, making them ideal for studying and understanding the effects of climate change. The CVCC project used a combination of scientific research and communitybased monitoring to study temperature ecology, mercury interactions, char biodiversity, and the importance of char to the northern ecosystem. Project results are critical to ensuring the sustainability of the fish, its continued supply as a food source, and the vitality of northern aquatic ecosystems.

Arctic Wildlife Observatories Linking Vulnerable EcoSystems (ArcticWOLVES) and its siter project Arctic Predators
An Early Warning System Using
Seabirds to Detect Ecosystem
Change in the High and Low Arctic

These projects monitored terrestrial wildlife species over several key sites spread around the Arctic Circle. One of the main goals was to establish a working set of common protocols so that monitoring of various ecosystems can easily be combined while producing the much-needed replicates to ease large-scale comparisons of various changes in arctic populations and dynamics.

During IPY monitoring of marine birds was intensified at several sites in Nunavut, with emphasis on comparisons with earlier work carried out in the 1970s and 1980s (Provencher et al. in press). The main aim was to use changes in the biology of the birds as indicators of change in local marine ecosystems. 
assess the impacts of global change on the world's migratory tundra caribou/reindeer (Rangifer sp.).

\subsection{Fish}

Great Slave Lake (GSL), Northwest Territories, supports the largest commercial freshwater fisheries for residents of this region (Rawson 1951; Keleher 1962). The combined harvest of lake whitefish (Coregonus clupeaformis) and lake trout (Salvelinus namaycush) peaked at 4,288 tonnes in 1948-1949 and has dropped below 1,000 tonnes since 2000. Almost the entire lake has been open to commercial fishing at some point in the history of the fishery, although certain areas have been closed to protect subsistence and sport fisheries (Read and Taptuna 2003). Collection of biological measurements and commercial harvest information has been sporadic (Read and Taptuna 2003; Tallman and Friesen 2007), but these data have allowed the examination of time-varying growth patterns of lake whitefish in response to changes in water level, riverine inflow, temperature, community structure, and exploitation (Zhu et al. 2011).

Arctic char, Salvelinus alpinus, have a circumpolar distribution and are the most adapted fish to cold-water habitat (Johnson 1980). In addition to its extraordinary importance to the arctic ecosystem, Arctic char is highly valued by Inuit and Aboriginal harvesters. Samples obtained along a $37^{\circ}$ latitudinal span (IPY-CVCC) indicated differences in length-at-age and age-specific growth rate and that fecundity varied with latitude, morphotype, life-history, and climate (Power et al. 2005; Chavarie et al. 2010; Loewen et al. 2010). Commercial fisheries for Arctic char in Cambridge Bay Nunavut commenced in 1960 and biological information was collected through fish plant sampling since 1971 (Day and de March 2004) providing a sporadic monitoring of relative abundance. Long-term (1960-2008) information on relative abundance, harvest history and biological observation, is being used to understand the relationship between Arctic char population biomass and large-scale climatic variables.

\subsection{Ice seals}

Collections of ringed seal (Pusa hispida) tissue parts from Arviat $\left(61^{\circ} \mathrm{N} 94^{\circ} \mathrm{W}\right)$ by subsistence hunters began in 1991 as part of a CWS study on polar bear prey. Collections continued sporadically to the present with an intense sampling occurring over the IPY period, 20032010 (IPY projects GWAMM and PET). Tissues from ringed, bearded (Erignathus barbatus), and harbour seals (Phoca vitulina) have been used to assess reproduction (ovaries and uterus; Holst et al. 1999), mating system (testes and bacula; Yurkowski et al. 2011), disease (Petersen et al. 2010), contaminants (McKinney et al. 2009), novel biomarker tissue (Ferreira et al. 2011), age structure (Ferguson et al. 2005), body condition (Chambellant 2010), and diet (Chambellant et al. 2012a; Young et al. 2010). Aerial surveys of ringed and bearded seal abundance in western Hudson Bay were initiated in spring 1995 and continued, with some gaps, to 2010 (Ferguson and Young 2011). GWAMM IPY funding provided the means to combine food habits, reproduction, and demographic information derived from tissue collections and aerial surveys and thereby provide evidence of decadal cycles in ice seal abundance (Chambellant et al. 2012b).

\subsection{Killer whales}

The GWAMM IPY project summarized killer whale (Orcinus orca) sightings from Canadian arctic waters and provided a unique dataset capable of determining long-term trends in sighting frequency, changes in distribution and relative abundance, and evidence of food habits (Higdon 2007; Higdon and Ferguson 2009; Ferguson et al. 2010; 2011; 2012a; 
Higdon et al. 2011). Inuit hunters throughout the eastern Arctic have reported recent increases in killer whale sightings and are concerned about the effects of increased predation on culturally-important marine mammals, and a research program was established in 2005 in response to these observations and concerns (Higdon 2007). A large spatial database of sighting reports has been developed (detailed in Higdon 2007; Higdon et al. 2011). To date, analyses of database records has provided important information on the spatiotemporal distribution and relative abundance of killer whales in different areas of the Canadian Arctic (Higdon 2007; Ferguson et al. 2010; 2011; Higdon et al. 2011), which has also been used to plan field research (e.g., Matthews et al. 2011). Inuit knowledge was collected via 105 semidirected interviews in 11 Nunavut communities from 2007-2010 (Ferguson et al. 2012a). Local hunters and elders have provided a wealth of information on killer whales, including many of the records in the sightings database, and analyses are on-going to understand longterm trends in the relative abundance of killer whales.

\subsection{Arctic marine birds}

Monitoring of marine bird reproductive success and colony size has proven to be an effective means of tracking the effects of anthropogenic stressors (fisheries, pollution, climate change) on marine ecosystems (Cairns 1987; Parsons et al. 2008). Monitoring has occured for several decades in the Canadian Arctic. Data on marine bird population in the Canadian Arctic used in this analysis come from: (1) Prince Leopold Island (PLI; $74^{\circ} \mathrm{N}, 90^{\circ} \mathrm{W}$ ) in the High Arctic, where population and breeding data have been gathered at irregular intervals since 1975 for three species (Thick-billed Murre Uria lomvia, Northern Fulmar Fulmarus glacialis, Blacklegged Kittiwake Rissa tridactyla; [Gaston et al. 2005a]); (2) Coats Island $\left(62^{\circ} \mathrm{N}, 82^{\circ} \mathrm{W}\right)$ in the low Arctic, where data on Thick-billed Murre numbers and reproduction have been gathered annually since 1985 (Gaston et al. 2009a). Prince Leopold Island has also been the site of long-term contaminants monitoring (Braune 2007). Methods typically involve daily observations on the attendance by parent birds and the fate of ca. 110-350 nests of each species, as well as overall numbers of birds observed on population monitoring plots at each colony (Gaston and Nettleship 1981; Gaston 2002; Gaston et al. 2006).

Results to date have highlighted the effects of ice conditions on the timing of breeding, the reproduction and the diets of Thick-billed Murres which make up the majority of marine birds at both colonies. In the high Arctic, timing of ice break-up in waters adjacent to PLI showed no secular trend, but was highly variable during 1976-2010 with murres changing their date of laying accordingly (Gaston et al. 2005b, AJG unpubl. data). In northern Hudson Bay there has been a significant trend towards earlier ice break-up, especially after the mid1990s. Coincidentally, prey fed to nestlings switched from Arctic cod (Boreogadus saida) to capelin (Mallotus villosus), a situation reflected in adult diets examined during the IPY project (Provencher et al. in press). Growth of nestlings has been adversely affected by a growing mismatch between ice break-up and the timing of egg-laying by murres (Gaston et al. 2009a). In light of the many new challenges experienced by marine birds due to changing environmental conditions (Gaston et al. 2009b; Mallory et al. 2010), the value of long-term monitoring, especially individual-based research, will probably increase in the future (e.g., Clutton-Brock and Sheldon 2010).

\subsection{Arctic fox}

Monitoring of Arctic foxes (Vulpes lagopus) started in 1993 on the south plain of Bylot Island $\left(73^{\circ} \mathrm{N}, 80^{\circ} \mathrm{W}\right)$, located in Sirmilik National Park. Monitoring increased gradually to 
include 40 dens (Szor et al. 2008) and then from 2003, all recorded dens ( 100$)$ were visited at least twice annually to look for signs of reproduction. About 20-30 adults and 20-60 juveniles were trapped every year. Information from different sources (live captures, automatic cameras, den observations) were used to estimate a yearly proportion of breeding foxes in the study population (Gauthier et al. 2004; Szor et al. 2008; Cameron et al. 2011; Giroux et al. 2012). Red foxes (Vulpes vulpes) are also monitored on Bylot Island but at most seven individuals and one reproductive den have been observed in the study area. Long-term ecological research has provided significant information on the influence of spatiotemporal variation of food on fox population dynamics (Bêty et al. 2002; Careau et al. 2008; Lecomte et al. 2008, 2009).

In addition to the Bylot Island monitoring data, the time series of Arctic fox fur returns in Nunavut from 1993 to 2008 was compiled to use harvest as a proxy for inter-annual change of this predator at a larger special scale (Lecomte $\mathrm{N}$, unpublished data). These data cover most of the Canadian Arctic from ca $60^{\circ} \mathrm{N}$ to $80^{\circ} \mathrm{N}$ and were obtained from Statistics Canada. According to this government agency (see their website), the data correlate with the reported harvest numbers for each species. Overlapped years displayed the same numerical values for winter. As each winter spanned over 2 years, we set the 'harvesting year' on the first of the 2 years to reflect the response of foxes following rodent presence during spring and summer.

\subsubsection{Time series analysis of long-term vertebrate data collections}

A body of analytical techniques has developed around long-term data collections relevant to the monitoring of biodiversity. Measures of biodiversity change can be estimated using standard measures such as Shannon or Simpson indexes (Buckland et al. 2004), and statistical measures such as Moran's I are used to account for temporal and spatial autocorrelation changes (Koenig 2004). To assess apparent biodiversity loss in response to an environmental stressor, like a new arctic fishery, requires a statistical assessment of uncertainty that the change differs from the baseline (Magurran et al. 2010). We used data from the above case studies (summarized in Table 2; Fig. 1) to illustrate several constructive methods that can be used to analyze time series data. Our study does not aim to be exhaustive, as we do not include a number of important arctic vertebrates such as marine fish, geese, and lemmings. Rather, we use this opportunity to present a region-wide perspective with a selection of data collections. The time series data used here will be made available on DRYAD, datadryad.org, an open-access repository of data underlying peer-reviewed, scientific articles. DRYAD's citable library already hosts numerous data packages and meta-data on adaptive management studies.

\subsubsection{Long-term Vertebrate Index (LVI)}

We calculated an index to display trends of time series data following the same approach used by the living planet index (LPI) (Loh et al. 2005; Collen et al. 2009). This allowed us to set the variety of our data collections within the same scale and compare them to trends observed at global, Canadian and arctic scales (Arctic Species Trends Index, ASTI) (Arctic Biodiversity Trends 2010; Butchart et al. 2010; World Wildlife Fund WWF 2010). These two former indices are built on the same mathematical logic than LVI and LPI. We derived these indices from the above publications as the raw data are not yet publicly available. In brief, the LVI is similar to the LPI and illustrates trends in population abundance or proxy of abundance using 1970 as a baseline (LVI=1 for 1970). For the LVI, we set a value of 1 to the first year of data if after 1970. Missing observations for times series data were interpolated using a gam-fitting framework (generalized additive modeling) and those with less than 6 years were estimated with a constant annual rate of change (Fewster et al. 2000; Loh et al. 
Table 2 Summary of long-term data collections analyzed to build a long-term vertebrate index (LVI) and to detect periodic variations in abundance

\begin{tabular}{llc}
\hline Species - population (abundance index used) & Temporal record & $\begin{array}{l}\text { Number } \\
\text { of years }\end{array}$ \\
\hline Polar bear - Western Hudson Bay (helicopter-assisted mark-recapture) & $1984-2004$ & 20 \\
Caribou - Migratory herds (aerial surveys) & $1976-2009$ & 34 \\
Lake whitefish - Great Slave Lake (harvest) & $1975-2010$ & 36 \\
Arctic char - Cambridge Bay (harvest) & $1975-2010$ & 36 \\
Ringed seal - Western Hudson Bay (aerial survey) & $1995-2000,2007-2010$ & 6,4 \\
Thick-billed murre - Prince Leopold Island (nest counts) & $1975-1988,2000-2010$ & 14,11 \\
Northern fulmar - Prince Leopold Island (nest counts) & $1975-1988,2000-2010$ & 14,11 \\
Black-legged kittiwake - Prince Leopold Island (nest counts) & $1975-1988,2000-2010$ & 14,11 \\
Thick-billed murre - Coats Island (nest counts) & $1985-2010$ & 26 \\
Killer whale - Canada (sightings) & $1977-2007$ & 31 \\
Arctic fox - Canada (fur harvests) & $1993-2008$ & 16 \\
Arctic fox - Bylot Island (den surveys) & $1996-2010$ & 15 \\
\hline
\end{tabular}

2005; Collen et al. 2009). The gam models allowed us to derive non-linear trends (e.g. the majority of the cases for caribou). We obtained the best-fitted gam values by comparing the estimated degree of freedom among possible models. We then aggregated fitted values among populations by species for each year to estimate on a log-scale the average annual rate of change. We performed 100,000 bootstraps to generate $95 \%$ confidence intervals around the LVI.

\subsubsection{Periodicity and density-dependence structure of time series data}

Wavelet analysis has been instrumental in describing ecological cycles and detecting gradual and sudden change in cyclicity (Cazelles et al. 2008; Ims et al. 2008) because it allows the decomposition of a time series data into a time-frequency space (Priestley 1992; Torrence and Compo 1998). We used this approach to identify when cyclic fluctuation may have occurred in our various data collections. The period of each cyclic dataset can be extracted from a wavelet power spectrum, which estimates the variance distribution for a given time point and scale. Significance can then be estimated with a point-wise test by comparing the power of the decomposed time series data with red-noise over different frequencies for all years to a rednoise background spectrum, treated as the null hypothesis (Priestley 1992; Torrence and Compo 1998). Red-noise here refers to any system where power density is decreasing with increasing frequency. We determined the critical values for the point-wise test by 10,000 Monte Carlo simulations. In wavelet analyses, time series data are extended with zero padding towards both ends, creating edge effects in the wavelet transformation. Outside the cone of influence where edge effects are present, interpretation should be made with caution (Torrence and Compo 1998).

Wavelet coherence allows the measure of statistical association between two time series in both time and frequency. When two normalized time series oscillate in a simultaneous manner (and whether there is a phase difference or not between the series), high coherence is expected and one series can predict the other (Torrence and Compo 1998; Grinsted et al. 2004). Lag period can then be derived with a phase spectrum (Maraun et al. 2008). We conducted wavelet analysis and wavelet coherence in R (R Development Core Team 2010) using the sowas package (Maraun and Kurths 2004; Maraun et al. 2008). We calculated a general estimate of large- 


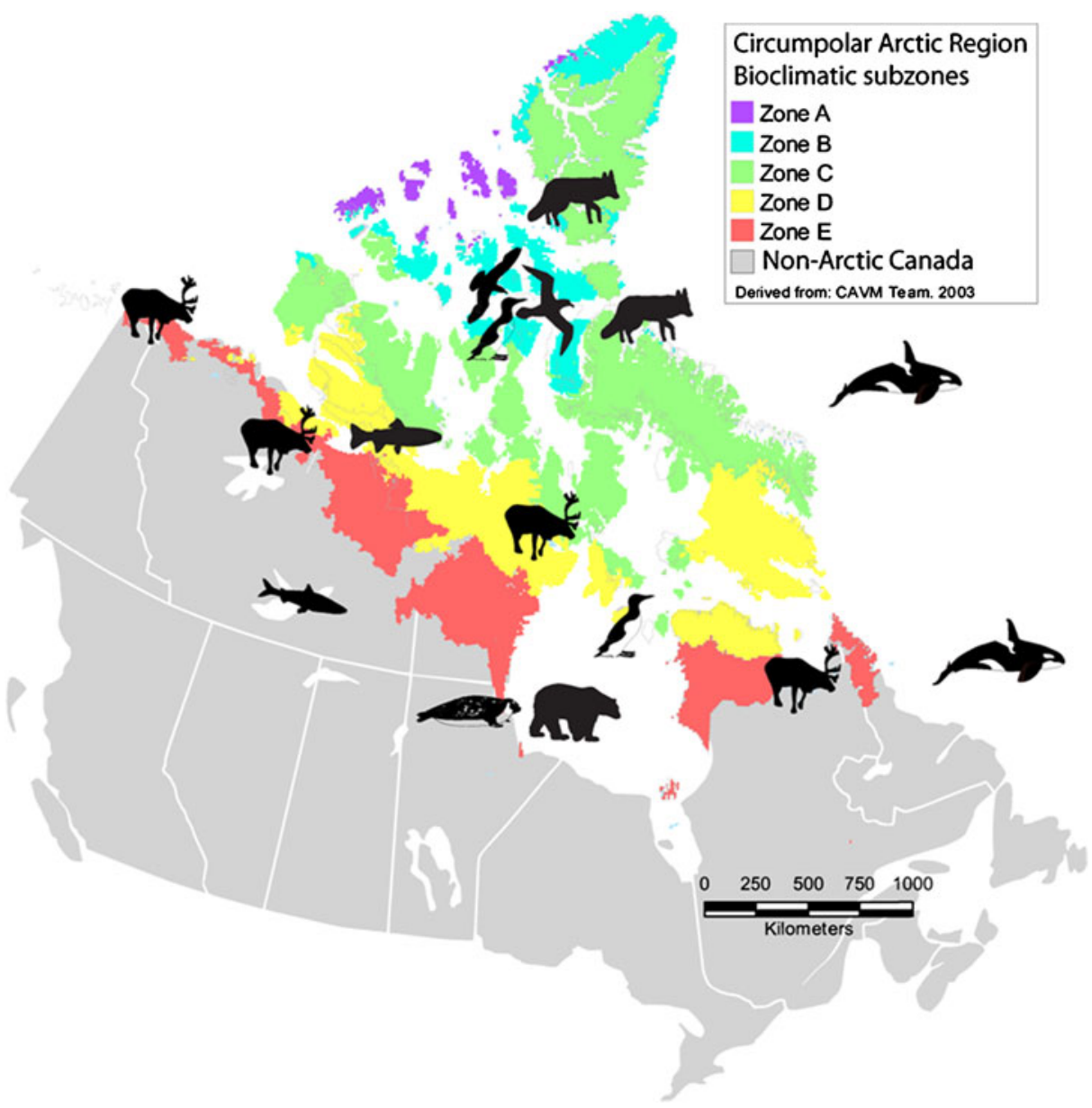

Fig. 1 Geographical regions represented by the long-term series data according to the different bioclimatic subzones of the Arctic (defined by Walker et al. 2005). Migratory caribou herds are located all across continental Canada

scale climatic variation on our time series data by running wavelet coherence and phase spectrum between all the continuous time series with the North-Atlantic Oscillation (NAO). Significant evidence has accumulated to show that this large-scale atmospheric phenomenon can simultaneously affect many species via an impact on local weather and vegetation. Overall, NAO is a possible indirect driver of various life histories traits and population dynamic parameters (e.g. Stenseth et al. 2002). We used both annual and winter NAO (December to March) indexes provided by the Climate Analysis Section, NCAR, Boulder, USA (Hurrell 1995).

To analyze density dependence, we used a second-order log-linear autoregressive [AR (2)] model, using the Yule-Walker estimators implemented in function ar.yw in the Rplatform (R Development Core Team 2010). This allowed us to extract the coefficients of direct density-dependence $\left(1+\beta_{1}\right)$ and delayed density-dependence $\left(\beta_{2}\right)$ for each time series (Shumway and Stoffer 2006). We imputted missing data in the seal time series data with log-linear interpolations. For data collections with too much missing data (i.e., seabirds at PLI and caribou), we estimated the best-fit line with $95 \%$ confidence limits 
from gam-model fitting series by series (see above for details). We removed any longterm trends in our time series data by fitting locally weighted regression to the logtransformed series for raw and corrected datasets and used the residuals to analyze density-dependence and cyclicity.

\subsection{Results}

\subsubsection{Long-term Vertebrate Index (LVI)}

Though the LPI (ca 2,500 species monitored over 8,000 populations) showed an overall decline in population abundance of about $30 \%$, Canadian (ca 393 species with 1,057 populations), Arctic (ca 193 species with 443 populations) and LVI indices ( 9 species with 21 populations) remained mostly above the reference level from 1970 to 2005 (Fig. 2). The LVI described a more exaggerated bell-shape compared to the two other indexes, with a general increase up to the 1990 s followed by a continuous decline of ca $30 \%$.

\subsubsection{Periodicity and density-dependence structure of time series data}

Wavelet analyses on detrended time series data (Fig. 3) detected a pattern of cyclicity only for killer whales, CI thick-billed murres, Arctic fox breeding dens and the Arctic char harvest series. Cyclicity was never constant though time, however, lasting at most for three cycle periods. For the lake whitefish population, we detected no periodicity, but this was the only time series data to exhibit a significant coherence with both the annual and winter North Atlantic Oscillation indexes (NAO). In Fig. 4, we only show the annual NAO to simplify the figure, though results are the same with the winter NAO. We detected a lag of 4 years between NAO and lake whitefish harvests with the wavelet phase specturm.

We plotted the density dependence coefficients on the parabola diagram of Royama (1977, 1992), where the relationship between the structure of density dependence and cyclicity can be shown (Fig. 5). Under the parabola, where delayed density dependence is relatively strong, periodical dynamics emerge, and the strength of direct density dependence affects the period length. In agreement with Fig. 5, only some of the populations (those below the semicircle) are expected to have cyclic dynamics.

\section{Discussion}

Our goal in this paper was to describe disparate data sources from long-term and IPYsupported monitoring of arctic vertebrates, analyse those data simultaneously to examine large-scale patterns of change, and discuss the consequent implications of long-term timeseries monitoring on science, management, and policy. Long-term monitoring of arctic vertebrate populations has been essential not only for developing policy and regulating harvest (Gaston and Robertson 2010; Peacock et al. 2010; Higdon et al. 2011), but also for input to international climate change analyses (Arctic Climate Impact Assessment ACIA 2005), regional land use planning and environmental assessment (Mallory and Fontaine 2004), and downlisting/uplisting species (Stirling and Parkinson 2006; Robertson et al. 2007). Funding and logistical support during IPY made significant contributions to longterm time series for arctic vertebrates, including the standardization of metadata, establishment of long term archives and improving access to collected data. IPY projects also increased the contribution of local Inuit knowledge to long-term data collections. 


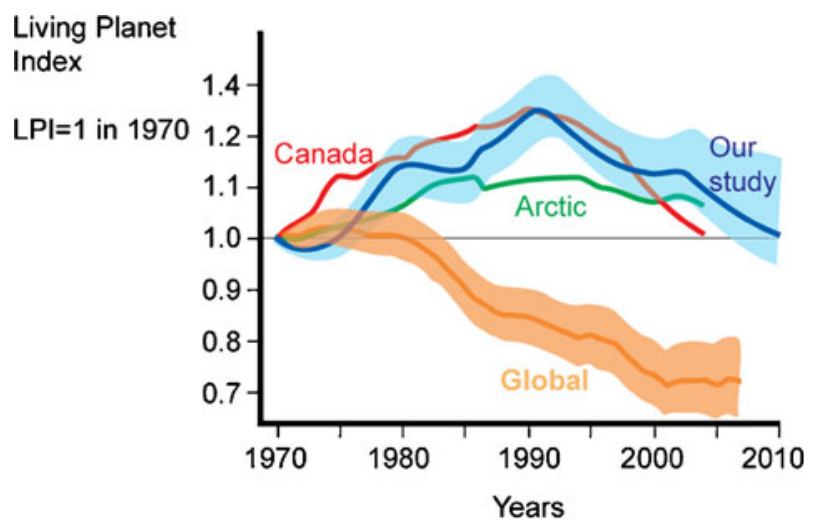

Fig. 2 Trend derived from the long-term monitoring case studies of some vertebrate populations in Canada (LVI, blue) compared to several global estimates using the living planet index (LPI). Mean global trend up to 2005 for all world species (orange), Canadian trend (red) and Arctic Species Trend Index (green). The Y-axis is ordinated on a logarithmic scale. Shades around the mean trends correspond to confidence intervals generated by bootstrap resampling

Information provided by Inuit hunters provides an example of how community-based monitoring can integrate local ecological knowledge and western science and fill large gaps in our existing monitoring systems (Ferguson et al. 2012a).

Collectively, the pooled data collections on arctic vertebrates exhibited some sharp departures from the global pattern in the living planet index (LPI). While the LPI has decreased roughly by $30 \%$ between 1970 and 2006 our long-term vertebrate index (LVI) is virtually similar in 2010 as it was in 1970. Part of this difference is likely due to the dramatic decrease in abundance $(59 \%)$ observed in many vertebrate populations from the tropics during the last three decades (Secretariat of the Convention on Biological Diversity 2010). Perhaps more interestingly, variations through time of our LVI are rather similar to variations in the Canadian or Arctic species trend indices (Fig. 2). We thus managed, from a handful of monitored vertebrate populations, to reproduce trends generated by indices using many more species and populations (Arctic species trend index: $n=306$ species and 965 populations, McRae et al. 2010). It would be useful if trends in arctic vertebrate populations would be homogenous enough that small sample sizes represent overall trends. However, this is not the case. When desintegrating the Arctic species trend index, McRae et al. (2010) indeed showed that populations in the High, Low and Sub-Arctic showed markedly different trends, ranging from an overall decline in abundance of $26 \%$ in High-Arctic species to an average $46 \%$ increase in Low-Arctic species over the same time period. While our monitored populations were representative of a larger pool of arctic populations, there continues to be a need for monitoring biodiversity at larger scales.

We also showed that some of the monitored vertebrate populations exhibited a transient cyclicity, but that only one (whitefish) showed a marked association with a broad climatic

Fig. 3 Population time series data across arctic Canada for seven marine, terrestrial, and freshwater species. Low-Arctic and arctic tundra series are illustrated in red and yellow, respectively. Raw and detrended values are shown as adjacent columns to emphasize the interannual variations in population dynamics (see methods for details). The y-axes of the detrended time series data are scaled differently among species and regions (i.e. minimum and maximum are series-specific) and thus the y-legend has been removed. Missing data present in the seal series were imputed with log-linear interpolations. The data on other Canadian caribou herds and seabirds from Prince Leopold Island are not presented because of too many missing data; the global trends of the seabird time series data are shown in Figure S1 
Raw estimates

Detrended time series
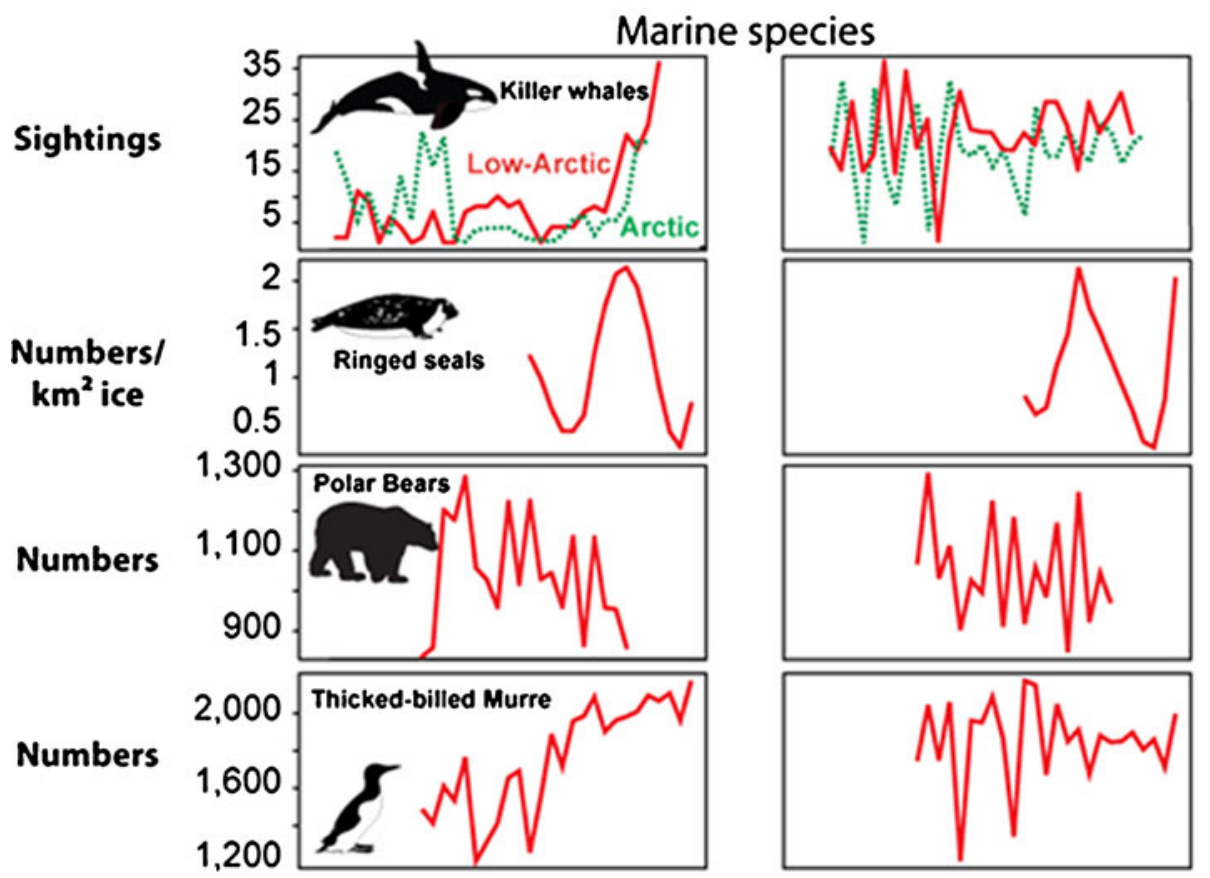

Terrestrial species
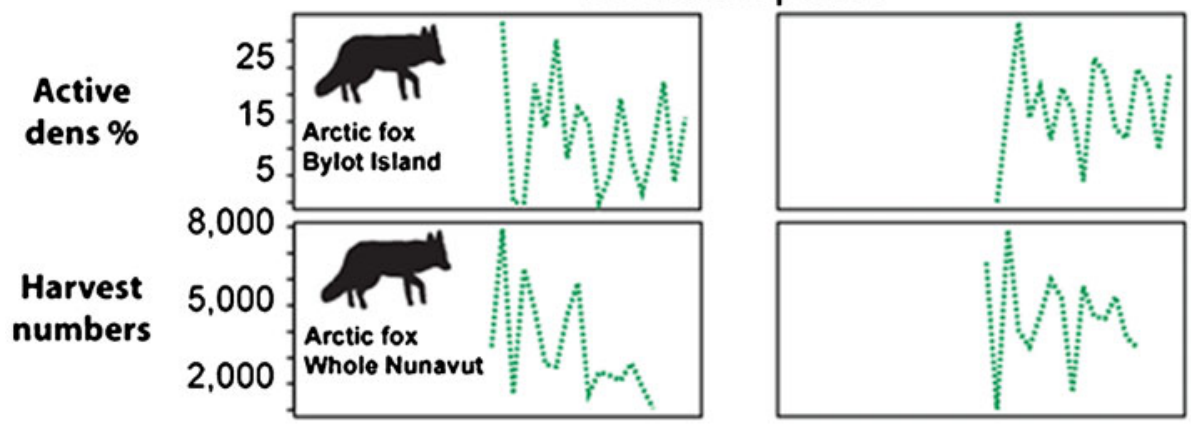

Freshwater species
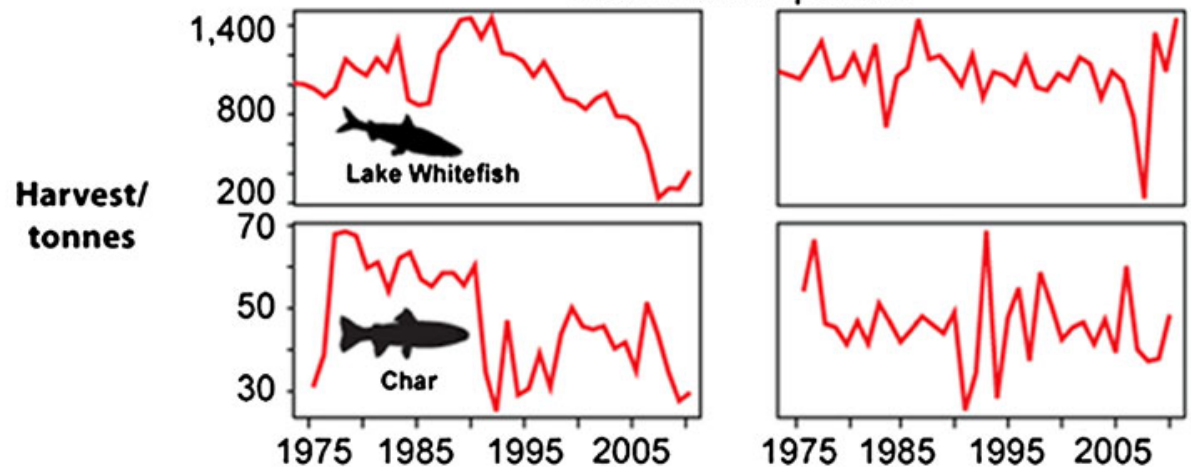

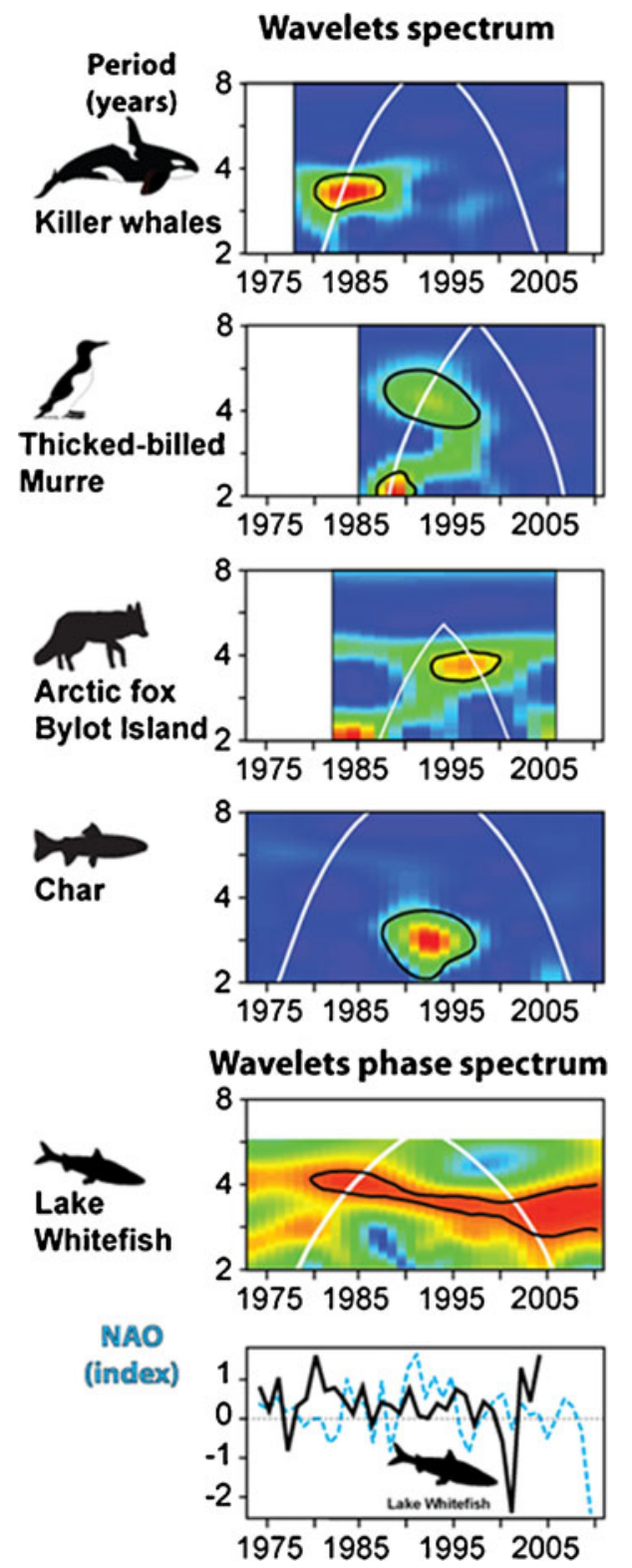

Fig. 4 Wavelet analyses results for five marine, terrestrial, and freshwater vertebrate species from across arctic Canada. Wavelet power spectrum identifies periods with significant periodicity. The magnitude (power) of the amplitude is visualized from dark blue for low power to dark red for high power, with significant periodicity bordered with dark lines (significant at the $5 \%$ level; 1,000 Monte Carlo simulations). White arched lines denote the cone of influence; outside such cones, interpretations should be made with caution. Other species described in the methods were excluded if no significant periodicity was detected. For the lake whitefish population, though no periodicity was detected, this was the only species to exhibit a significant coherence with the annual North Atlantic Oscillation index (NAO). Thus, temporal dynamics of the NAO is displayed at the bottom of the figure, together with the detrended time series data of the lake white fish, slided by -4 years to illustrate the 4 -years lag between the two series demonstrated by the phase spectrum above 


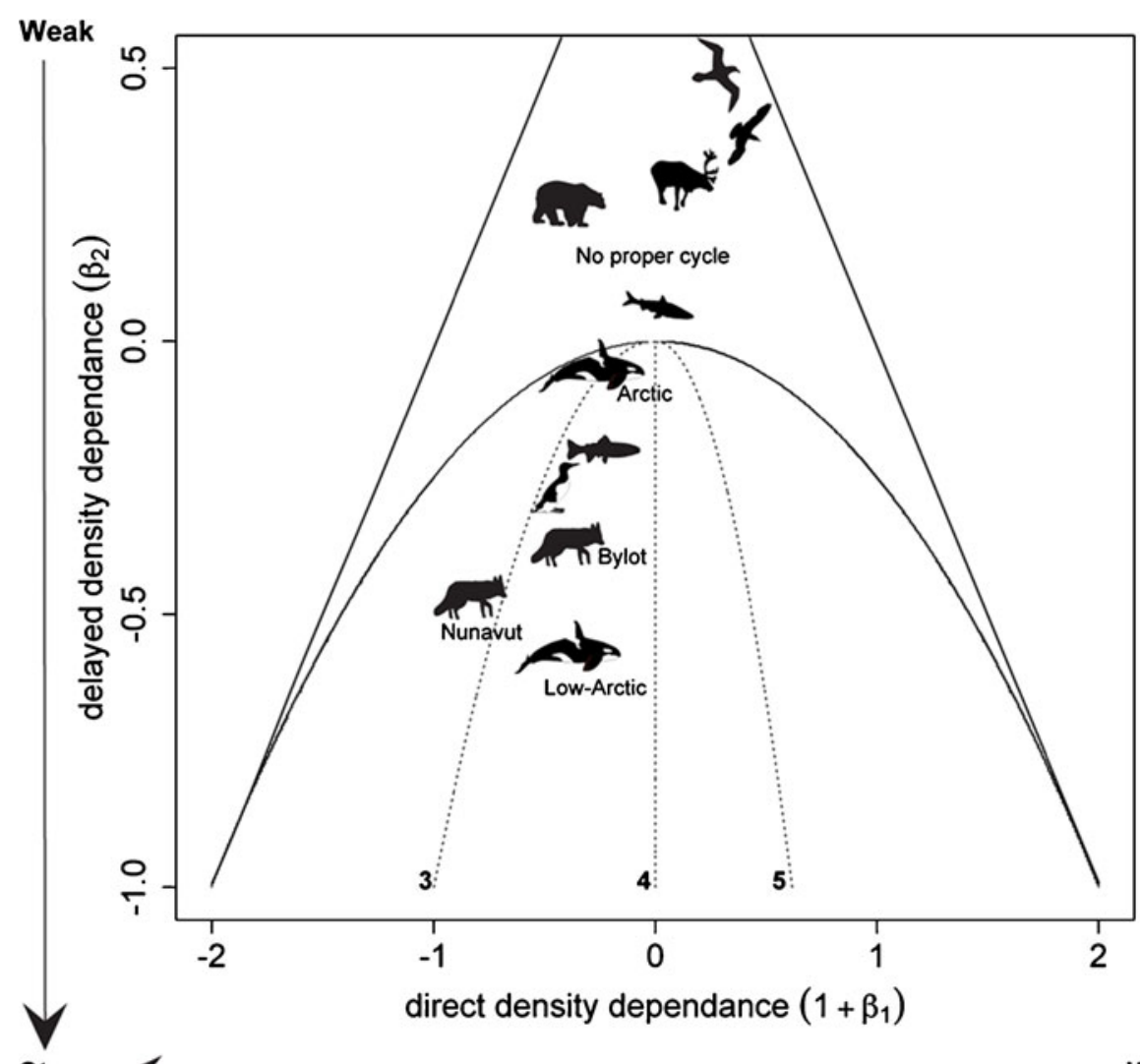

Strong

Weak

Fig. 5 Estimated coefficients for most of our vertebrate time series data for direct versus delayed density dependence $(1+\beta 1$ vs. $\beta 2)$ plotted in the framework of the parameter plane of the second-order log-linear model $[\mathrm{AR}(2)]$. The expected cycle period lengths are illustrated with the dotted isoclines increasing from left to right (i.e. 3, 4 and 5 years). Arrows indicate two routes toward cycle collapse: (1) with increasing strength of direct density dependence that leads to period shortening, and (2) a decreased strength of delayed density dependence that leads to period lengthening

pattern like the NAO. Our finding that the Arctic fox showed ca. 4 year cycles is not surprising, given that such cycles have been described in their main prey, lemmings (e.g. Gruyer et al. 2008; Lecomte et al. 2008). The transient cycles observed in e.g. killer whales or Arctic char were not synchronized with each other, which suggest no direct link between these patterns. The association between whitefish and NAO is more interesting and might generate testable hypotheses about potential cause-effect relationships. Typically, long causal chains and indirect effects make correlations much more abundant than mechanistic understanding in ecology (Krebs and Berteaux 2006).

The monitoring supported by IPY not only augmented the existing time series data collections, but provided some specific new projects and new discoveries, such as the observation of plastic pollution in thick-billed murres (Provencher et al. 2010). This had not been observed in Canadian arctic seabirds or in this species previously, but data now suggest that up to one in 10 of these birds has ingested plastic garbage that now pervades all parts of the world's oceans. Such evidence derived from monitoring can be used by policy makers to 
enact laws to reduce plastic debris in Canadian marine waters. Another new discovery was that poor environmental conditions during the previous winter can have a marked, deleterious effect on survival of thick-billed murres (Smith and Gaston in press). Furthermore, IPY support provided new data on the increasing presence and range expansion of killer whales (Higdon and Ferguson 2009), and cycling predator-prey dynamics between polar bears and seals. IPY also generated new quantified evidence for the striking ability of some arctic terrestrial wildlife species to use the marine environment over large spatial scales, probably due to the steep productivity gradient between the two environments (e.g. Gagnon and Berteaux 2009; Tarroux et al. 2010; Giroux et al. 2012). The IPY-generated killer whale sightings database (Higdon 2007; Higdon et al. 2011) is dominated by observations from local resource users and indicated the great value of local knowledge that can assist in understanding ecosystem changes and improve adaptive management (Ferguson et al. 2012b).

\subsection{Scientific value of long-term data}

Conflicts occur between short-term, specific hypothesis testing and the collection of consistent long-term life-history and environmental data. Arctic researchers measuring biological variables face the difficulty of continuously sampling remote environments while confronting and overcoming financial constraints and technical difficulties compared to measuring chemical and physical environmental indices (e.g., Mallory et al. 2006). As a result of funding cycles, currently the majority of time series data are peppered with spatial and temporal gaps (McDonald-Madden et al. 2010). For example, migratory tundra caribou herds generally cycle every $40-50$ years. By understanding the timing, frequency and amplitude of these cycles, we are better able to identify the drivers of change and thus predict impacts of unidirectional changes such as climate change and industrial development.

One future need of Canada's current arctic monitoring sites is to develop single-species studies into multiple trophic levels over a broad spatial scale (e.g. Lecomte et al. 2009). Currently, most arctic observation programs focus on only a few trophic levels and emphasize the top of the virus-to-whale spectrum. Collectively, the collation of disparate data from knowledgeable local residents, marine bird monitoring, marine mammal monitoring, etc., allows for more comprehensive and thorough understanding of the effects of environmental change on arctic environments (e.g., Ferguson et al. 2010).

A circumpolar monitoring network is needed to invest in research and monitoring that emphasizes community engagement. With greater temporal and spatial coverage of ecological data, the scale of management issues that can be addressed increases considerably. The Canadian Arctic is relatively unique in having a good spatial representation of small communities with local inhabitants closely tied to the land and sea and having a rich cultural history of traditional local ecological knowledge. Creating a network of monitoring sites does not necessarily require new infrastructure but rather use of the existing multi-agency partnerships including for example, monitoring and assessment activities of the Arctic Monitoring and Assessment Program (AMAP) and the Conservation of Arctic Flora and Fauna (CAFF) working groups of the Arctic Council. The Circumpolar Biodiversity Monitoring Program (CBMP) of CAFF may be particularly relevant. These efforts can be linked with existing Canadian community-based monitoring systems such as Ecological Monitoring and Assessment Network (EMAN) and with other pan-arctic efforts (e.g., and Sustaining Arctic Observing Networks (SAON)). Monitoring programs can build on the current momentum observed in Nunavut (Nunavut General Monitoring Program, NGMP) to involve local people 
in designing and implementing surveys and summarizing results that can be used for management.

\subsection{How do long-term time series data help in management?}

Adaptive management refers to a management approach that changes and develops as new results are assessed as well as actively using management to learn about the system. The method contrasts with the crisis management approach typically used by decision-makers. The adaptive management cycle includes implementing management actions determined from prior objectives, evaluating their success, adjusting the strategy according to the evaluation process, and continuing the sequence with iterative improvements (Carpenter and Gunderson 2001). Longterm monitoring assists in the adaptive management cycle by providing background threshold levels against which change can be compared and its significance evaluated. Merging ecosystem model studies with long-term observations provides the ability to include less-studied functional groups or the ones that are more difficult to monitor in the management strategy evaluation process (Edwards et al. 2010; Hoover 2010; Hoover et al. 2011).

For example, the fox data included here were used as part of a long-term evaluation of the ecological integrity of Sirmilik National Park and the monitoring therefore has strong local conservation value. The arctic fox, like the polar bear, has become a climate change flagship species (International Union for Conservation of Nature IUCN 2009) because tundra habitat may be slowly replaced by subarctic vegetation, accompanied by the northward encroachment of the competitively superior red fox, a process already documented. Milder and shorter winters are predicted to cause declines in lemmings, the main source food of Arctic fox. Harvest time series data for this species provide interannual variations that correlate with population dynamics, and harvest data may provide good proxies for monitoring yearto-year variation of many populations (Hersteinsson et al. 1989).

In the Great Slave Lake system, lake whitefish is important to aboriginal commercial and subsistence uses and the sustainable management of this species is a priority for local communities. Fisheries and Oceans Canada implemented a long-term sampling program, including collection of age structures from harvests in each management area and sporadic surveys to produce abundance indices (Tallman and Friesen 2007). The primary driving force behind water level fluctuation and fish growth (Mohr and Ebener 2005) was found to be climate-driven precipitation variability in the Peace-Athabasca basins (Gibson et al. 2006). Long-term (1960-2010) data indicated a significant negative correlation between fish condition index and riverine inflow, and this information assisted in local management (Zhu et al. 2011).

Marine bird population monitoring in arctic Canada has been key in developing or influencing policies to understand the effects of climate change on these species (Gaston et al. 2005a,b), as well as for understanding changes in food webs that might affect reproduction (Gaston et al. 2003). For murres, an internationally-harvested species, these monitoring data also contribute to setting harvest limits and understanding the effects of harvest quotas on sustainable management (Gaston and Robertson 2010). The data also constitute Canada's contribution to the International Murre Conservation Strategy (Conservation of Arctic Flora and Fauna CAFF 1996). These data, as well as additional work at other monitoring sites (e.g., Gaston et al. 2006; Love et al. 2010; Mallory et al. 2009), form critical information for input to land use planning in Nunavut, environmental assessments, and protected areas development and management (Mallory and Fontaine 2004).

Monitoring population status of caribou herds allows managers to know where they are in the cycle, how to adjust management actions to dampen fluctuations at population peaks and hasten recovery at population lows (Vors and Boyce 2009). Recognizing where we are 
on the cycle needs to be incorporated into cumulative impact assessments such that impacts can be expressed at the population level rather than at the behavioural or habitat selection level.

\subsection{How do the data help in developing policy?}

Policy-makers make decisions based on expert knowledge, existing research, results of statistical analyses of change, and by consulting with stakeholders (Fletcher 2007). Problems can occur when decision-makers try to account for scientific uncertainty, ignorance, and unexpected surprises (McDaniel and Driebe 2005). There is a growing need for simple methods of communicating uncertainty to policy-makers. The International Panel on Climate Change (Intergovernmental Panel on Climate Change IPCC 2005) recommended transparently describing reasonably likely changes, even when uncertain, in a narrative scale of confidence and likelihood (Mastrandrea and Mache 2011; however see Jonassen and Pielke 20110). Rudd et al. (2011) recently generated priority research questions to inform biodiversity conservation policy and management in Canada. They stressed that evidencebased policy-making is increasingly being advocated and used in conservation. Many key policy-driven questions concern the effects of climate change on terrestrial and aquatic ecosystems. Answers require that the data distinguish anthropogenically-induced climate change patterns from natural variability. Two of the most pressing environmental issues concern climate change and biodiversity loss. Data on the effects of climate change on biodiversity are thus important to inform policy makers. The northward progression of isotherms in the Arctic will have wide-ranging impacts on the distribution of wildlife, with cascading effects on the functioning of ecosystems. Many arctic species may undergo population declines in response to warming (Rohani and King 2010), and long-term data on wildlife populations ultimately have strong relevance to policy.

Another policy question concerns how to conduct adaptive management in the context of an ecosystem-based approach. Conservation monitoring provides information needed to improve the adaptive management process and inform policy (McDonald-Madden et al. 2010). For example, conventional approaches to marine fisheries management have not performed as needed (Worm et al. 2009) resulting in a call for innovative approaches including a more holistic ecosystem approach to management (Pikitch et al. 2004). An ecosystem approach requires an appropriate monitoring system that extends to biological as well as current physical and chemical observations and humans and associated stressors. Reliable data on species distribution and abundance, across multiple trophic levels, is a significant information need. For example, a better understanding of population abundance of large caribou herds would prevent conflicts between government policies and regulations and the recommendations and actions of co-management boards, as was experienced during recent population lows of a number of herds.

\subsection{Conclusions and future recommendations}

The focus of this article has been on the value of long-term biological data obtained (to varying extents) during the most recent IPY years, 2007-08, and summarizing the contribution of long-term ecological monitoring to science, management, and policy in the Arctic. We recommend using every opportunity to advocate for the collection of long-term data in ecological science to improve both temporal and spatial extent (Carpenter 2002). Such data are particularly important in monitoring human impacts as they enable us to understand natural variation over time and space (Micol and Jouventin 2001). Without long-term data we cannot disentangle the putative causes of environmental change, or determine whether 
change is natural or anthropogenic in origin, nor can we understand the significance of such change in both statistical and biological relevant contexts.

To facilitate integration of information on biological time trends, Canada needs to develop the capacity to archive, retrieve, and exchange long-term data, so that the data outlive their collectors. A discussion is required as to who takes on this added responsibility for centralized monitoring in any new major role - should it be government or universities or locals? The need for a centralized leadership suggests that governments take on this responsibility primairly. Similar themes that are open to discussion include developing continuity and integrity of data and associated data sharing and data management. We need to develop statistical techniques to make full use of long-term data including condensation of source data into derived products that are simple temporal and spatial aggregations necessary for policy. Furthermore, we must integrate long-term data into data networks and develop better ways (e.g., statistical techniques) to relate them to each other. We need to find new technologies and approaches so that derived data products can be synthesized for ecosystem use. Lastly, new findings derived from long-term data needs must be used to inform policy to guide decision-making, thereby closing the feedback cycle.

Key findings include:

1. maintain existing ecological time series data, particularly those with $>10$ years. Continue past methodology as well as adopting internationally accepted monitoring approaches and integrate data collections with physical and chemical observations in a more regional perspective for comparability.

2. internally expand existing long-term surveys into a greater spatial pattern and expand current programs into a more diversified trophic sampling program by adding new sampling methodologies and technologies and experimental and process studies. Uniting ongoing observational studies with management programs and policy decisionmaking efforts will maximize funding opportunities (e.g., developing an ecosystem approach to management with added spatial and temporal value).

3. externally expand beyond the original program goals to allow for integrated monitoring programs at large scales useful for monitoring change while controlling for natural environmental background patterns. Delineating new geographical locations for additional site monitoring requires development of a centralized plan.

4. integrate by collecting and assimilating disparate biological monitoring programs around the circumpolar Arctic. Develop consistent systematic approaches to data collection and availability to ensure public accessibility and the opportunity to combine similar long-term data collections globally. An integrated and sustained observational approach will provide assessment of global climate change patterns through international collaboration.

Acknowledgments Many people and organizations have contributed to the collection of long-term data collections. Financial and logistical support came from a variety of sources including: ArcticNet Centre of Excellence, Canada Foundation for Innovation, Canada Research Chairs program, Churchill Northern Study Center, Environment Canada, Fisheries and Oceans Canada, Indian and Northern Affairs Canada, Federal Program of the Canadian International Polar Year, Government of Nunavut, Natural Sciences and Engineering Research Council, Nunavut Wildlife Management Board, Fisheries Joint Management Coucil, and a number of universities (University of Alberta, University of Quebec Rimouski, University of Manitoba, University of British Columbia, Carleton University, University of Ottawa). We also extend our thanks to the editorial review panel. 


\section{References}

Arctic Biodiversity Trends (2010) Selected indicators of change. CAFF International Secretariat, Akureyri

Arctic Climate Impact Assessment (ACIA) (2005) Arctic climate impact assessment. Cambridge University Press, Cambridge

Bêty J, Gauthier G, Korpimäki E, Giroux JF (2002) Shared predators and indirect trophic interactions: lemming cycles and arctic nesting geese. J Anim Ecol 71:88-89

Bezemer TM, van der Putten WH (2007) Diversity and stability in plant communities. Nature 446:E6-E7

Blunden J, Arndt DS, Baringer MO, (eds) (2011) State of the climate in 2010. Bull Amer Meteor Soc 92(6): S1-S266

Braune BM (2007) Temporal trends of organochlorines and mercury in seabird eggs from the Canadian arctic, 1975-2003. Environ Pollut 148(2):599-613

Buckland ST, Magurran AE, Green RE, Fewster RM (2004) Monitoring change in biodiversity through composite indices. Phil Trans R Soc London Ser B 360:243-254

Butchart S, Wallpole M, Collen B, van Strien A, Scharlemann J et al (2010) Global biodiversity: indicators of recent declines. Science 328(5982):1164-1168

Cairns DK (1987) Seabirds as indicators of marine food supplies. Biol Oceanogr 5:261-272

Cameron C, Berteaux D, Dufresne F (2011) Spatial variation in food availability predicts extrapair paternity in the arctic fox. Behav Ecol 22:1364-1373

Careau V, Lecomte N, Bêty J, Giroux JF, Gauthier G et al (2008) Hoarding of pulsed resources: temporal variations in egg-caching by arctic fox. Ecoscience 15(2):268-276

Carpenter S (2002) Ecological futures: building an ecology of the long now. Ecology 83(8):2069-2083

Carpenter SR, Gunderson LH (2001) Coping with collapse: ecological and social dynamics in ecosystem management. Bioscience 51:451-457

Carpenter S, Armbrust EV, Arzberger PW, Chapin FS, Elser JJ et al (2009) Accelerate synthesis in ecology and environmenta sciences. Bioscience 59(8):699-701

Cazelles B, Chavez M, Berteaux D, Menard F, Vik JO et al (2008) Wavelet analysis of ecological time series. Oecologia 156:287-304

Chambellant M (2010) Hudson Bay ringed seal: ecology in a warming climate. In: Ferguson SH, Loseto LL, Mallory ML (eds) A little less Arctic: top predators in the world's largest northern inland sea, Hudson Bay. Springer, New York, pp 137-158

Chambellant M, Stirling I, Gough WA, Ferguson SH (2012a) Temporal variations in Hudson Bay ringed seal (Phoca hispida) life-history parameters in relation to environment. J Mammal 93:267-281

Chambellant M, Lunn NJ, Ferguson SH (2012b) Temporal variation in distribution and density of iceobligated seals in western Hudson Bay, Canada. Pol Biol. doi:10.1007/s00300-012-1159-6

Chavarie L, Dempson JB, Schwarz CJ, Reist JD, Power G et al (2010) Latitudinal variation in growth among Arctic charr in eastern North America: evidence for countergradient variation? Hydrobiologia 650:161-177

Clutton-Brock T, Sheldon BC (2010) Individuals and populations: the role of long-term, individual-based studies of animals in ecology and evolutionary biology. Trends Ecol Evol 25:562-573

Collen B, Loh J, Whitmee S, Mcrae L, Amin R et al (2009) Monitoring change in vertebrate abundance: the living planet index. Conserv Biol 23:317-327

Conservation of Arctic Flora and Fauna (CAFF) (1996) International murre conservation strategy and action plan. Arctic Environmental protection strategy. Conservation of Arctic Flora and Fauna International Secretariat, Akureyri

Day AC, de March B (2004) Status of Cambridge Bay anadromous Arctic char stocks. Canadian Science Advisory Secretariat Research Document 2004/052, 85p

Dillon PJ, Molot LA, Futter M (1997) The effect of El Niño-related drought on the recovery of acidified lakes. Environ Monit Assess 46(1-2):105-111

Edwards M, Beaugrand G, Hays GC, Koslow JA, Richardson AJ (2010) Multi-decadal oceanic ecological datasets and their application in marine policy and management. Trends Ecol Evol 25(10):602-610

Eicken H, Jones J, Rohith MV, Kambhamettu C, Meyer F et al (2011) Environmental security in Arctic ice-covered seas: from strategy to tactics of hazard identification and emergency response. Mar Technol Soc J 45(3):37-48

Ferguson SH, Young BG (2011) Review of aerial survey estimates for Ringed Seals (Pusa hispida) in western Hudson Bay, 2009 and 2010. DFO Canadian Science Advisory Secretariat. Science Advisory Report, 2011/024

Ferguson SH, Stirling I, McLoughlin P (2005) Climate change and ringed seal (Phoca hispida) recruitment in Hudson Bay. Mar Mamm Sci 21(1):121-135

Ferguson SH, Loseto LL, Mallory ML (2010) A little less Arctic: changes to top predators in the world's largest Northern inland sea, Hudson Bay. Springer, Dordrecht 
Ferguson SH, Higdon JW, KH Westdal (2012a) Prey items and predation behavior of killer whales (Orcinus orca) in Nunavut, Canada based on Inuit hunter interviews. Aquatic Biosystems 8:3 http:// www.aquaticbiosystems.org/content/8/1/3.

Ferguson SH, Kingsley MCS, Higdon JW (2012b) Killer whale predation in a multi-prey system. Popul Ecol 54(1):31-41. doi:10.1007/s10144-011-0284-3

Ferreira EO, Loseto LL, Ferguson SH (2011) Assessment of ringed seal (Phoca hispida) claw growth-layergroups as biomonitors of inter- and intra-annual $\mathrm{Hg}, \mathrm{d}^{15} \mathrm{~N}$ and $\mathrm{d}^{13} \mathrm{C}$ variation. Can J Zool 89(9):774-784

Fewster RM, Buckland ST, Siriwardena GM, Baillie SR, Wilson JD (2000) Analysis of population trends for farmland birds using generalized additive models. Ecology 81:1970-1984

Fletcher S (2007) Converting science to policy through stakeholder involvement: an anlaysis of the European marine strategy directive. Mar Poll Bull 54(12):1881-1886

Gagnon CA, Berteaux D (2009) Integrating traditional ecological knowledge and ecological science: a question of scale. Ecol Soc 14(2):19

Gaston AJ (2002) Studies of high latitude seabirds. 5. Monitoring thick-billed murres in the eastern Canadian Arctic, 1976-2000. Can Wildl Serv Occas Pap 106:1-52

Gaston AJ, Nettleship DN (1981) The thick-billed murres of prince Leopold Island. vol 6. Canadian Wildlife Service. Monograph Series no. 6. Ottawa

Gaston A, Robertson GJ (2010) Trends in the harvest of Brunnich's guillemots Uria lomvia in Newfoundland: effects of regulatory changes and winter sea ice conditions. Wildlife Biol 16(1):47-55

Gaston AJ, Woo K, Hipfner JM (2003) Trends in forage fish populations in northern Hudson Bay since 1981, as determined from the diet of nestling thick-billed murres Uria lomvia. Arctic 56(3):227-233

Gaston AJ, Gilchrist HG, Mallory ML (2005a) Variation in ice conditions has strong effects on the breeding of marine birds at Prince Leopold Island, Nunavut. Ecography 28(5):331-344

Gaston AJ, Gilchrist HG, Hipfner JM (2005b) Climate change, ice conditions and reproduction in an Arctic nesting marine bird: Brunnich's guillemot (Uria lomvia L.). J Anim Ecol 74(5):832-841

Gaston AJ, Mallory ML, Gilchrist HG, O’Donovan K (2006) Status, trends and attendance patterns of the Northern Fulmar Fulmarus glacialis in Nunavut, Canada. Arctic 59(2):165-178

Gaston AJ, Gilchrist HG, Mallory ML, Smith PA (2009a) Changes in seasonal events, peak food availability and consequent breeding adjustment in a marine bird: a case of progressive mis-matching. Condor 111(1):111119

Gaston AJ, Bertram DF, Boyne AW, Chardine JW, Davoren G et al (2009b) Changes in Canadian seabird populations and ecology since 1970 in relation to changes in oceanography and food webs. Environ Rev 17:267-286

Gauthier G, Bety J, Giroux J-F, Rochefort L (2004) Trophic interactions in a High Arctic Snow Goose colony. Integr Comp Biol 44:119-129

Gibson JJ, Prowse TD, Peters DL (2006) Hydroclimatic controls on water balance and water level variability in Great Slave Lake. Hydrol Processes 20:4155-4172

Giroux MA, Berteaux D, Lecomte N, Gauthier G, Szor G, Bêty J (2012) Benefiting from a migratory prey: spatio-temporal patterns in allochthonous subsidization of an arctic predator. J Anim Ecol 81:533-542

Gofman V (2010) Community based monitoring handbook: lessons from the Arctic, CAFF CBMP Report No.21, August 2010, CAFF International Secretariat, Akureyri, Iceland. ISBN 978-99799778-4-1

Grinsted A, Moore JC, Jevrejeva S (2004) Application of the cross wavelet transform and wavelet coherence to geophysical time series. Nonlinear Process Geophys 11:561-566

Gruyer N, Gauthier G, Berteaux D (2008) Cyclic dynamics of sympatric lemming populations on Bylot Island, Nunavut, Canada. Can J Zool 86:910-917

Harwell MA, Gentile JH (2006) Ecological significance of residual exposures and effects from the Exxon Valdez oil spill. Integrated Environ Assess Manag 2(3):204-246

Hersteinsson P, Angerbjorn A, Frajord K, Kaikusalo A (1989) The arctic fox in Fennoscandia and Iceland: management problems. Biol Cons 49:67-81

Higdon JW (2007) Status of knowledge on killer whales (Orcinus orca) in the Canadian Arctic. Fisheries and Oceans Canada Canadian Science Advisory Secretariat Research, Document 2007/048, Fisheries and Oceans Canada, Ottawa, ON

Higdon JW, Ferguson SH (2009) Loss of Arctic sea ice causing punctuated change in sightings of killer whales (Orcinus orca) over the past century. Ecol Appl 19:1365-1375

Higdon JW, Hauser D, Ferguson SH (2011) Killer whales (Orcinus orca) in the Canadian Arctic: distribution, prey items, group sizes, and seasonality. Mar Mamm Sci. doi:10.1111/j.1748-7692.2011.00489.x

Holst M, Stirling I, Calvert W (1999) Age structure and reproductive rates of ringed seals (Phoca hispida) on the Northwestern coast of Hudson Bay in 1991 and 1992. Mar Mamm Sci 15:1357-1364 
Hoover C (2010) Hudson Bay ecosystem: past, present, and future. In: Ferguson SH, Loseto LL, Mallory ML (eds) A little less Arctic: top predators in the world's largest northern inland sea, Hudson Bay. Springer, Dordrecht, pp 217-236

Hoover C, Pitcher T, Christensen V (2011; in press) Impacts of hunting, fishing, and climate change to the Hudson Bay marine ecosystem 1970-2009. Ecol Modell

Hurrell J (1995) NAO index data provided by the climate analysis section, NCAR, Boulder, USA. Online: http://www.cgd.ucar.edu/cas/jhurrell/indices.html

Ims RA, Henden JA, Killengreen ST (2008) Collapsing population cycles. Trends Ecol Evol 23:79-86

Intergovernmental Panel on Climate Change (IPCC) (2005) AR4 Guidance notes for lead authors of the IPCC fourth assessment report on addressing uncertainties, http://www.ipcc.ch/pdf/supportingmaterial/uncertainty-guidance-note.pdf

International Union for Conservation of Nature (IUCN) (2009) Species and climate change: more than just polar bear. Report of the Species Survival Commission of the IUCN

Jeffries DS (1997) 1997 Canadian acid rain assessment Volume 3. The effects on Canada's lakes, rivers and wetlands. Environment Canada, Gatineau

Johnson L (1980) The Arctic charr, Salvelinus alpinus. In: Balon EK (ed) Charr: salmonid fishes of the genus Salvelinus. Dr. W. Junk, The Hagus, pp 15-98

Jonassen R, Pielke R Jr (20110) Improving conveyance of uncertainties in the findings of the IPCC. Clim Change 108:745-753

Keleher JJ (1962) A documented review of Great Slave Lake commercial catch regulations. Fisheries Research Board of Canada Manuscript Report Series 715

Kirby RR, Beaugrand G, Lindley JA, Richardson AJ, Edwards M et al (2007) Climate effects and benthicpelagic coupling in the North Sea. Mar Ecol Prog Ser 330:31-38

Koenig WD (2004) Spatial autocorrelation of ecological phenomena. Trends Ecol Evol 14(1):22-26

Krebs CJ, Berteaux D (2006) Problems and pitfalls in relating climate variability to population dynamics. Climate Res 32:143-149

Lecomte N, Careau V, Gauthier G, Giroux JF (2008) Predator behaviour and predation risk in the heterogeneous Arctic environment. J Anim Ecol 77:439-447

Lecomte N, Ehrich D, Ims RA, Yoccoz NG (2009) Toward understanding the effect of top-predators on ecosystems. F-1000 Biology Reports, 1, 26-29. doi:10.3410/B1-26

Likens GE, Bormann FH (1974) Acid rain: a serious regional environmental problem. Science 184 (4142):1176-1179

Lindenmayer DB, Likens GE, Krebs CJ, Hobbs RJ (2010) Improved probability of detection of ecological « surprises ». Proc Nat Acad Sci 107(51):21957-21962

Loewen TN, Gillis D, Tallman RF (2010) Maturation, growth and fecundity of Arctic charr, Salvelius alpinus (L.), life-history variants co-existing in lake systems of southern Baffin Island, Nunavut, Canada. Hydrobiol 650:193-202

Loh J, Green RE, Ricketts T, Lamoreux J, Jenkins M et al (2005) The living planet index: using species population time series data to track trends in biodiversity. Phil Trans Roy Soc Lond Ser B 360:289295

Love OP, Gilchrist HG, Descamps S, Semeniuk C, Bêty J (2010) Pre-laying climatic cues can time reproduction to optimally match offspring hatching and ice conditions in an Arctic marine bird. Oecologia $164: 277-286$

Magurran AE, Baillie SR, Buckland ST, Dick J, Elston DA et al (2010) Long-term datasets in biodiversity research and monitoring: assessing change in ecological communities through time. Trends Ecol Evol 25 (10):574-582

Mallory ML, Fontaine AJ (2004) Key marine habitat sites for migratory birds in Nunavut and the Northwest Territories. Can Wildl Serv Occas Pap 109

Mallory ML, Ogilvie C, Gilchrist HG (2006) A review of the Northern Ecosystem Initiative in Arctic Canada: facilitating Arctic ecosystem research through traditional and novel approaches. Environ Monit Assess 113(1-3):19-29

Mallory ML, Akearok JA, Gaston AJ (2009) Status of black-legged kittiwake (Rissa tridactyla) colonies in the Canadian high Arctic. Arctic 62(1):96-101

Mallory ML, Gaston AJ, Gilchrist HG, Robertson GJ, Braune BL (2010) Effects of climate change, altered sea-ice distribution and seasonal phenology on marine birds. In: Ferguson S, Loseto L, Mallory M (eds) A little less Arctic: changes to top predators in the world's largest Northern inland sea, Hudson Bay. Springer, Dordrecht, pp 179-195

Maraun D, Kurths J (2004) Cross wavelet analysis: significance testing and pitfalls. Nonlinear Process Geophys 11:505-514 
Maraun D, Kurths J, Holschneider M (2008) Nonstationary Gaussian processes in wavelet domain: synthesis, estimation, and significance testing. Phys Rev 75:016707

Mastrandrea MD, Mache KJ (2011) Treatment of uncertainties in IPCC Assessment reports: past approaches and considerations for the Fifth Assessment Report. Clim Change 108:659-673

Matthews C, Luque SP, Petersen SD, Andrews RD, Ferguson SH (2011) Satellite tracking of a killer whale (Orcinus orca) in the eastern Canadian Arctic documents ice avoidance and rapid, long-distance movement into the North Atlantic. Pol Biol 34:1091-1096. doi:10.1007/s00300-010-0958-x

McDaniel RR Jr, Driebe DJ (2005) Uncertainty and surprise in complex systems: questions on working with the unexpected. Springer, Berlin

McDonald-Madden E, Baxter P, Fuller RA, Martin TG, Game ET et al (2010) Monitoring does not always count. Trends Ecol Evol 25(10):547-550

McKinney MA, Peacock E, Letcher RJ (2009) Sea ice-associated diet change increases the levels of chlorinated and brominated contaminants in polar bears. Environ Sci Technol 43(12):4334-4339

McRae LC, Zöckler C, Gill M, Loh J, Latham J et al (2010) Arctic species trend index 2010: tracking trends in Arctic Wildlife. CAFF CBMP Report No. 20, CAFF International Secretariat, Akureyri, Iceland

Micol T, Jouventin P (2001) Long-term population trends in seven Antarctic seabirds at Pointe Geologie (Terre Adelie): human impact compared with environmental change. Pol Biol 24(3):175-185

Mohr LC, Ebener MP (2005) Status of Lake Whitefish (Coregonus clupeaformis) in Lake Huron. In: Mohr LC, Nalepa TF (eds) Proceedings of a workshop on the dynamics of lake whitefish (Coregonus clupeaformis) and the Amphipod Diporeia spp. in the Great Lakes. Great Lakes Fishery Commission Technical Report 66, Ann Arbor, MI, pp 105-125

Möllmann C, Müller-Karulis B, Kornilov G, St John MA (2008) Effects of climate and overfishing on zooplankton dynamics and ecosystem structure: regime shifts, trophic cascade, and feedback loops in a simple ecosystem. ICES J Mar Sci 65(3):302-310

Ottoboni A, Bissell GD, Hexter AC (1977) Effects of DDT on reproduction in multiple generations of beagle dogs. Arch Environ Con Tox 6(1):83-101

Parsons M, Mitchell I, Butler A, Ratcliffe N, Frederiksen M et al (2008) Seabirds as indicators of the marine environment. ICES J Mar Sci 65:1520-1526

Peacock E, Derocher AE, Lunn NJ, Obbard ME (2010) Polar bear ecology and management in Hudson Bay in the face of climate change. In: Ferguson SH, Loseto LL, Mallory ML (eds) A little less Arctic: top predators in the world's largest northern inland sea, Hudson Bay. Springer Publishing Company, Pages 93-116

Peters D (2010) Accessible ecology: synthesis of the long, deep, and broad. Trends Ecol Evol 25(10):592-601

Peters D, Groffman PM, Nadelhoffer KJ, Grimm NB, Collins SL et al (2008) Living in an increasingly connected world: a framework for continental-scale environmental science. Front Ecol Environ 6(5):229-237

Petersen SD, Hainstock M, Wilson PJ (2010) Population genetics of Hudson Bay marine mammals: current knowledge and future risks. In: Ferguson SH, Loseto LL, Mallory ML (eds) A little less Arctic: top predators in the world's largest northern inland sea, Hudson Bay. Springer, New York, pp 237-266

Pikitch EK, Santora C, Babcock EA, Bakun A, Bonfil R et al (2004) Ecosystem-based fishery management. Sci 305:346-347

Post E, Forchhammer M, Bret-Harte MS et al (2009) Ecological dynamics across the Arctic associated with recent climate change. Sci 325:1355-1358

Power M, Dempson JB, Reist JD, Schwarz CJ, Power G (2005) Latitudinal variation in fecundity among Arctic charr populations in eastern North America. J Fish Biol 67:255-273

Priestley M (1992) Spectral analysis and time series. Academic, Princeton

Provencher JF, Gaston AJ, Mallory ML, O’Hara P, Gilchrist HG (2010) Ingested plastic in a diving seabird, the thick-billed murre (Uria lomvia), in the eastern Canadian Arctic. Mar Pollut Bull 60(9):1406-1411

Provencher JF, Gaston AJ, O’Hara P, Gilchrist HG (in press) Seabird diet indicates changing Arctic marine communities in eastern Canada. Mar Ecol Prog Ser

R Development Core Team (2010) R: a language and environment for statistical computing. R Foundation for Statistical Computing, Vienna

Rawson DS (1951) Studies of the fish of Great Slave Lake. J Fish Res Board Can 8b(4):207-240

Read CJ, Taptuna WEF (2003) Data from the commercial fishery for lake whitefish, Coregonus clupeaformis (Mitchill), on Great Slave Lake, Northwest Territories, 1999/00 to 2001/02. Can Data Rep Fish Aquat Sci 1111: v+54 p

Regehr EV, Lunn NJ, Amstrup SC, Stirling I (2007) Effects of earlier sea ice breakup on survival and population size of polar bears in Western Hudson Bay. J Wildl Manage 71(8):2673-2683

Robertson GJ, Gilchrist HG, Mallory ML (2007) Colony dynamics and persistence of Ivory Gull breeding in Canada. Avian Conserv Ecol 2:8 
Rohani P, King AA (2010) Never mind the length, feel the quality: the impact of long-term epidemiological data sets on theory, application and policy. Trends Ecol Evol 25(10):611-618

Royama T (1977) Population persistence and density dependence. Ecol Monogr 47:1-35

Royama T (1992) Analytical population dynamics. Chapman \& Hall, London

Rudd MA, Beazley KF, Cooke SJ, Fleishman E, Lane DE et al (2011) Generation of priority research questions to inform conservation policy and management at a national level. Conserv Biol 25:476-484

Secretariat of the Convention on Biological Diversity (2010) Global biodiversity outlook 3.

Shumway RH, Stoffer DS (2006) Time series analysis and its applications, with R examples. Springer Science, New York

Smith PA, Gaston AJ (in press) Demography, diet and chick-provisioning in thick-billed Murres in relation to environmental conditions in the breeding and non-breeding seasons. Mar Ecol Prog Ser

Stenseth NC, Mysterud A, Ottersen G, Hurrell JW, Chan KS et al (2002) Ecological effects of climate fluctuations. Sci 297:1292-1296

Stirling I, Parkinson CL (2006) Possible effects of climate warming on selected populations of polar bears (Ursus maritimus) in the Canadian Arctic. Arctic 59:261-275

Stirling I, Spencer C, Andriashek D (1989) Immobilization of polar bears (Ursus maritimus) with Telazol in the Canadian Arctic. J Wildl Dis 25(2):159-168

Szor G, Berteaux D, Gauthier G (2008) Finding the right home: distribution of food resources and terrain characteristics influence selection of denning sites and reproductive dens in arctic foxes. Pol Biol 31 (3):351-362

Tallman RF, Friesen MK (2007) A review of population trends in length and age of lake whitefish (Coregonus clupeaformis) harvested from Great Slave Lake between 1972 and 1995. Can Manu Rep Fish Aqua Sci No 2819

Tarroux A, Berteaux D, Bêty J (2010a) Northern nomads: ability for extensive movements in adult arctic foxes. Pol Biol 33(8):1021-1026

Torrence C, Compo GP (1998) A practical guide to wavelet analysis. Bull Am Meteorol Soc 79:61-78

Vors LS, Boyce MS (2009) Global declines of caribou and reindeer. Global Change Biol 15:2626-2633

Walker DA, Raynolds MK, Daniels FJA, Einarsson E, Elvebakk A et al (2005) The circumpolar Arctic vegetation map. J Veg Sci 16:267-282

World Wildlife Fund (WWF) (2010) Living planet report. In: Grooten M, McLellan R, Oerlemans N, Zwaal N (eds) WWF in association with Zoological Society of London \& Global Footprint Network, Leusden, Netherlands

Worm B, Hilborn R, Baum JK, Branch TA, Collie JS et al (2009) Rebuilding global fisheries. Sci 325(5940):578-585

Young BG, Loseto LL, Ferguson SH (2010) Diet differences among age classes of Arctic seals: evidence from stable isotope and mercury biomarkers. Pol Biol 33:153-162

Youngblut C (2009) Climate change: issues in the science and its use. Institute for Defence Analyses, Alexandra

Yurkowski D, Chambellant M, Ferguson SH (2011) Bacular and testicular growth and allometry in the aquatic-mating ringed seal (Pusa hispida): evidence of polygyny? J Mammal 92(4):803-810

Zhu X, Day AC, Taptuna W, Carmichael TJ, Tallman RF (2011) Hierarchical modeling of spatiotemporal dynamics of biological characteristics of Lake Whitefish, Coregonus clupeaformis (Mitchill), in Great Slave Lake, Northwest Territories, Canada. CSAS Res. Docu. 2011/XXX, ix 